\title{
Prospects for therapeutic Helicobacter pylori vaccines
}

\begin{abstract}
Helicobacter pylori was first isolated from human stomach biopsies in 1983 [1]. The human stomach is the only known ecological niche for $H$. pylori, and untreated the stomach remains infected for life, despite a vigorous host immune response. In developing countries, $>80 \%$ of adults may be infected and infection is widespread among children and infants [2]. In developed countries, the prevalence has dropped to $30-50 \%$ over the last 20 years and infection is found mainly in adults. Of the infected adults, c. $20 \%$ develop gastric disease, and $H$. pylori is the major cause of peptic ulcers, duodenal ulcers and gastritis. Long-term infection may result in B-cell lymphoma and adenocarcinoma of the stomach [3]. The International Agency for Research on Cancer, which is affiliated to the World Health Organization, attributes $55 \%$ of stomach cancers $(500000 /$ year $)$ to $H$. pylori. In 3-17-year-old Peruvian children infected with $H$. pylori, gastritis is the most frequent ailment [4]. Bangladeshi and Gambian infants, who acquire $H$. pylori within a few months after birth, often have diarrhoea and are malnourished [5-7]. Peptic and duodenal ulcers can be treated effectively with a short course of two antimicrobial agents and a proton pump inhibitor such as omeprazole [8], but prevention of infection would obviously be preferable.
\end{abstract}

H. pylori infection meets two important criteria that give it a high priority for vaccine development [9]: the infection is widespread in both developing and developed countries; and it causes a considerable burden of illness in developed countries. The cost of development of a vaccine is likely to be retrieved once it is used in the developed world, and revenues may help to subsidise the price for poorer countries. Price is important, as vaccines may be the only way to treat $H$. pylori infections on a large scale in developing countries.

The cost of combination therapy and the emergence of antibiotic resistance provide further incentives for vaccine development. Widespread use of combination therapy for gastric disease symptoms, often without prior confirmation of the presence of $H$. pylori, puts pressure on national health budgets [10] and has probably caused the emergence of antibiotic resistance among $H$. pylori isolates [11]. Resistance of $H$. pylori to metronizadole or clarithromycin has risen sharply in
European countries and results in lower success rates for combination therapy [8]. In Hong Kong 70-80\% of isolates are resistant to metronizadole. Resistance is also common in developing countries. Emergence of multi-drug-resistant $H$. pylori will further limit the efficacy of combination therapy. Therapeutic vaccines could be used in addition to current regimens to treat infections with antibiotic-resistant $H$. pylori, while prophylactic vaccination could prevent $H$. pylori infection in adults and children on a large scale. An analogy can be made with typhoid. In south-east Asia, quinolone-resistant typhoid fever poses serious public health problems in an area where multi-drug resistance in Salmonella enterica serotype Typhi is already common $[12,13]$. In such a scenario, immunisation is essential for the prevention and control of epidemics and infection in children $[9,13]$.

So far vaccination studies have achieved only limited success. Two questions remain unanswered: what are the protective antigens; and can the quality of immune response be influenced by mucosal adjuvants? Infection with $H$. pylori drives a T-helper (Th) 1 response $[14,15]$. Studies in man $[6]$ and in mice $[15,16]$ have shown that protection is associated with a Th2 response, marked by the production of IgA and IgG1 respectively. In animal studies, mucosal adjuvants such as cholera toxin (CT) and heat-labile toxin of Escherichia coli (LT) are required to induce a Th2 response against $H$. pylori antigens [17]. Use of these enterotoxins in man is limited, as low doses cause diarrhoea in volunteers [17], but a genetically detoxified LT (LTK63), which retains mucosal adjuvanticity in mice, has been described [18]

A candidate vaccine antigen should be immunogenic, surface exposed and conserved among genetically diverse $H$. pylori isolates, which can be divided into two pathotypes: type I strains, which contain the s1 allele of the vacuolating cytotoxin gene, vacA; and type II strains which contain the s2 allele [19]. Type I strains also contain the cytotoxin-associated gene, $\operatorname{cag} A$. This is a marker for a pathogenicity island, which contains a gene cluster encoding factors instrumental in the inflammation of the stomach epithelium $[19,20]$. Type II strains are non-toxigenic and lack cag $A$ and the pathogenicity island. There is a significant association between type I strains and 
peptic ulcer disease in Europeans and North Americans [19], but not among Japanese and Korean patients harbouring type I isolates [21]. The adaptation of $H$. pylori to the human stomach has led to the hypothesis that some isolates (possibly type II strains) may be commensals and may even be beneficial for the host [3].

The first evidence that immunisation could prevent helicobacter infection came from the $H$. felis mouse model. Oral immunisation of mice with $H$. felis sonicate and CT, or with the B subunit of the urease holo-enzyme of $H$. pylori (UreB) and CT, prevented infection by $H$. felis. Urease is considered essential for colonisation of the stomach by $H$. pylori [17]. The use of UreB and CT as a therapeutic vaccine has been studied in ferrets, which carried $H$. mustelae. In immunised animals, inflammation of the stomach was reduced, but infection was eradicated in only $30 \%$ of the animals [17]. Oral administration of urease did not cause any side-effects in human volunteers seropositive for $H$. pylori. When asymptomatic adults were given four doses of urease and LT in a phase II trial, the number of bacteria was significantly decreased, but $H$. pylori was not eradicated and most volunteers developed diarrhoea [11].

VacA, GroES, catalase and urease are antigens exposed at the surface of $H$. pylori $[19,22,23]$. All strains express GroES, catalase and urease, but VacA is expressed only by type I strains. The combination of a mucosal adjuvant with either catalase [22], VacA [17] or GroES [16] prevented helicobacter infection in mice, but immunisation with VacA did not protect against infection with a type II strain [17]. Thus, a monovalent vaccine can select for a certain phenotype, and escape mutants of $H$. pylori might be generated by vaccination with a single antigen. To determine whether immunisation with the UreB antigen could have a similar effect, phenotypic variation of UreB in different $H$. pylori isolates is currently under investigation at this laboratory. A multivalent vaccine is likely to induce a more effective bactericidal immune response. Higher levels of protection were achieved by immunisation of mice with a combination of UreB and GroES than with the separate antigens [16].

In $H$. pylori, outer-membrane proteins and porins form a large family of 32 genes [24]. These proteins, which are surface exposed and well conserved, may be excellent vaccine candidates [24,25]. Oral immunisation with a combination of LTK63 and urease, VacA or CagA protected mice against $H$. pylori infection [26], and immunisation with VacA or CagA also eradicated existing chronic infection [27]. Although detoxified mucosal adjuvants still have to prove their safety in human trials, a multi-component vaccine with detoxified mucosal adjuvants shows promise.

A vaccine shown to be successful in an animal model might take several years to be proven safe and efficacious in man [17]. If such a formulation is found, field trials in children as well as adults will be necessary. However, the incidence of $H$. pylori infection in childhood may be too low for field trials to produce useful results in developed countries. Indeed they may be deemed unethical and uneconomical. In developing countries paediatric infection is common and is associated with gastritis, hypochlorhydria, malnutrition and diarrhoea [4, 7]. Field trials of a paediatric $H$. pylori vaccine would best be held in such areas. Therapeutic application of an $H$. pylori vaccine as an addition to current treatment regimens should provide the impetus for the development of an efficacious vaccine for this ubiquitous and versatile pathogen.

S.G.T. RIJPKEMA Division of Bacteriology, National Institute of Bacteriological Standards and Control, Potters Bar, Herts. EN6 3QG UK e-mail: srijpkema@nibsc.ac.uk

\section{References}

1. Warren JR, Marshall BJ. Unidentified curved bacilli on gastric epithelium in active chronic gastritis. Lancet 1983; 1: 12731275.

2. Feldman RA, Eccersley AJP, Hardie JM. Transmission of Helicobacter pylori. Curr Opin Gastroenterol 1997; 13 Suppl 1: 8-12.

3. Blaser MJ. Not all Helicobacter pylori strains are created equal: should all be eliminated? Lancet 1997; 349: 1020-1022.

4. Begue RE, Gonzales JL, Correa Grocian H, Tang SC. Helicobacter pylori infection in children with abdominal ailments in a developing country. Am J Med Sci 1997; 314: 279-283.

5. Mahalanabis D, Rahman MM, Sarker SA et al. Helicobacter pylori infection in the young in Bangladesh: prevalence, socioeconomic and nutritional aspects. Int J Epidemiol 1996; 25: $894-898$.

6. Thomas JE, Austin S, Dale A et al. Protection by human milk $\operatorname{IgA}$ against Helicobacter pylori infection in infancy. Lancet 1993; 342: 121

7. Dale A, Thomas JE, Darboe MK, Coward WA, Harding M, Weaver LT. Helicobacter pylori infection, gastric acid secretion, and infant growth. J Pediatr Gastroenterol Nutr 1998; 26: 393-397.

8. Tytgat GNJ. Aspects of anti-Helicobacter pylori eradication therapy. In: Hunt RH Tytgat GNJ (eds) Helicobacter pylori basic mechanisms to clinical cure. Amsterdam, Kluwer. 1996: 340-347.

9. Levine MM, Levine OS. Influence of disease burden, public perception, and other factors on new vaccine development, implementation, and continued use. Lancet 1997; 350: 1386-1392.

10. Greener M. Funding of omeprazole: a burning issue. Pharmaceutical Times 1998; March 16.

11. Michetti P. Vaccines against Helicobacter pylori: fact or fiction? Gut 1997; 41: 728-730.

12. Parry C, Wain J, Chinh NT, Vinh H, Farrar JJ. Quinoloneresistant Salmonella typhi in Vietnam. Lancet 1998; 351: 1289.

13. Ivanoff B, Levine $M$. Typhoid fever: continuing challenges from a resilient bacterial foe. Bull Inst Pasteur 1997; 95: $129-142$.

14. D'Elios MM, Manghetti $\mathrm{M}$, De Carli $\mathrm{M}$ et al. $\mathrm{T}$ helper 1 effector cells specific for Helicobacter pylori in the gastric antrum of patients with peptic ulcer disease. J Immunol 1997; 158: $962-967$

15. Mohammadi M, Nedrud J, Redline R, Lycke N, Czinn SJ. Murine CD4 T-cell response to Helicobacter infection: TH1 cells enhance gastritis and $\mathrm{TH} 2$ cells reduce bacterial load. 
Gastroenterology 1997; 113: 1848-1857.

16. Ferrero RL, Thiberge J-M, Kansau I, Wuscher N, Huerre M, Labigne A. The GroES homolog of Helicobacter pylori confers protective immunity against mucosal infection in mice. Proc Natl Acad Sci USA 1995; 92: 6499-6503.

17. Lee A, Buck F. Vaccination and mucosal immune responses to Helicobacter pylori infection. Aliment Pharmacol Ther 1996; 10 Suppl 1: 129-138.

18. Pizza M, Fontana MR, Giulliani MM et al. A genetically detoxified derivative of heat-labile Escherichia coli enterotoxin induces neutralizing antibodies against the A subunit. $J$ Exp Med 1994; 180: 2147-2153.

19. Cover TL. The vacuolating cytotoxin of Helicobacter pylori. Mol Microbiol 1996; 20: 241-246.

20. Censini S, Lange C, Xiang Z et al. cag, a pathogenicity island of Helicobacter pylori, encodes type I-specific and diseaseassociated virulence factors. Proc Natl Acad Sci USA 1996; 93 : $14648-14653$.

21. Ito $\mathrm{Y}$, Azuma $\mathrm{T}$, Ito $\mathrm{S}$ et al. Analysis and typing of the vacA gene from cagA-positive strains of Helicobacter pylori isolated in Japan. J Clin Microbiol 1997; 35: 1710-1714.
22. Radcliff FJ, Hazell SL, Kolesnikow T, Doidge C, Lee A. Catalase, a novel antigen for Helicobacter pylori vaccination. Infect Immun 1997; 65: 4668-4674.

23. Phadnis SH, Parlow MH, Levy M et al. Surface localization of Helicobacter pylori urease and a heat shock protein homolog requires bacterial autolysis. Infect Immun 1996; 64: 905-912.

24. Tomb J-F, White O, Kerlavage AR et al. The complete genome sequence of the gastric pathogen Helicobacter pylori. Nature 1997; 388: 539-547.

25. Doig P, Trust TJ. Identification of surface-exposed outer membrane antigens of Helicobacter pylori. Infect Immun 1994; 62: 4526-4533.

26. Marchetti M, Rossi M, Giannelli V et al. Protection against Helicobacter pylori infection in mice by intragastric vaccination with $H$. pylori antigens is achieved by using a non-toxic mutant of E. coli heat-labile enterotoxin (LT) as adjuvant. Vaccine 1998; 16: 33-37.

27. Ghiara $\mathrm{P}$, Rossi $\mathrm{M}$, Marchetti $\mathrm{M}$ et al. Therapeutic intragastric vaccination against Helicobacter pylori in mice eradicates an otherwise chronic infection and confers protection against reinfection. Infect Immun 1997; 65: 4996-5002. 